\title{
Correction to: The Psychobiology of Hunger - A Scientific Perspective
}

\author{
Kristine Beaulieu ${ }^{1} \mathbb{C} \cdot$ John Blundell ${ }^{1}$
}

Published online: 10 November 2020

(c) The Author(s) 2020

\section{Correction to: Topoi}

https://doi.org/10.1007/s11245-020-09724-z

In the original article, the section heading was incorrectly published. The heading of section 8 should read as "Nomothetic and Idiographic Principles" rather than "Omothetic and Idiographic Principles".

Open Access This article is licensed under a Creative Commons Attribution 4.0 International License, which permits use, sharing, adaptation, distribution and reproduction in any medium or format, as long as you give appropriate credit to the original author(s) and the source, provide a link to the Creative Commons licence, and indicate if changes

were made. The images or other third party material in this article are included in the article's Creative Commons licence, unless indicated otherwise in a credit line to the material. If material is not included in the article's Creative Commons licence and your intended use is not permitted by statutory regulation or exceeds the permitted use, you will need to obtain permission directly from the copyright holder. To view a copy of this licence, visit http://creativecommons.org/licenses/by/4.0/.

Publisher's Note Springer Nature remains neutral with regard to jurisdictional claims in published maps and institutional affiliations.

The original article can be found online at https://doi.org/10.1007/ s11245-020-09724-z.

Kristine Beaulieu

k.beaulieu@leeds.ac.uk

1 School of Psychology, Faculty of Medicine and Health,

University of Leeds, Leeds LS2 9JT, UK 